一特 集 比較教育学研究第25号〔1999年〕

比較教育学の新展開—その可能性と展望

\title{
比較教育学と地域研究 (2)
}

一オセアニア地域研究の立場から—

\section{1. オセアニア地域の現状と研究の意義}

ニュージーランド大使館が1995年に出した「日本に括けるニュージーランド研 究の促進」で、「21世紀が近づく中で、アジア太平洋地域は急速に変貌している。 貿易、投資、移住及び交流を通して、地域内の人々同志の接触は急速に拡大して いる。新たな協力の精神が、APECの発展や、新しいASEAN 地域フォーラムを 通して具体的に発揮されつつある。このよらな背景のもとでは、我々が隣人を知 ることが、これまでにも増して重要になり、多様性に富も地域では、教育は明ら かに人々の将来の異文化間交流に備えさせる上で中心的役割を担ら。これらの広 範囲に及ぶ変化は、教育界に対し数多くの緊急の課題を突きつけている」と記し ている。少し長い引用になったが、同趣旨の内容がオーストラリア大使館広報部 が毎年刊行している『豪日関係』(The Australia-Japan Relationship) にもみら れ、これらオセアニア地域の 2 大国がアジア太平洋地域に積極的に関心を向け、 かつ教育が望ましい関係を樹立するための中心的役割を果たすべきことを明示し ている。

一方、我が国でも第15期中央教育審議会第 1 次答申の「国際化と教育」（第三部 第 2 章）で「我が国はあらゆる面において、これまでとかく欧米先進諸国に目を 向けがちであった。（中略）今後はアジア諸国やオセアニア諸国など様々な国々 にも一層目を向けていく必要がある」と、この地域に関心を向ける必要性のある ことを述べている。

確かに世界はより鮮明に三極構造化する様相を見せはじめてきたといえる。西 ヨーロッパ圏の10数カ国は共通通貨のユーロの導入を契機に世界の一大勢力を形 
特集 比較教育学の新展開—その可能性と展望

成する勢いであり、世界の超大国を自負するアメリカは南北アメリカ大陸に摇る ぎない影響力を維持している。その狭間にあってアジミ平洋地域は経済、貿易、 政治など多くの面で遅れをとり、軽視されてきたことは多くの人の認めるところ であるが、東アジアや東南アジア、オセアニア地域のもつ人的な潜在力は今後の 世界に無視できない存在になることは明らかである。これは、世界的な情報通信 技術の発達がこれらの動きを急速に加速し、21世紀を迎えるに当たり従来とは全 く違った様相の兆しが既に生じているからである。我々は、発展途上国と先進国 の経済格差から生じた大量の移民、民族意識の高まり、先住民族の人権の保障な ぞ、世界的な規模で生じている諸問題を厳しく検証することが迫られている。

この中にあり、我が国の教育研究は欧米中心で、従来アジア太平洋地域、特に オセアニア地域を対象とする教育研究を軽視してきたといっても過言ではない。

上記の『豪日関係』には「オセアニア諸国と日本の間での類似点と相違点の研究 は、比較研究の優れた基礎的経験となる。異なった歴史的、社会的、経済的背景 は、一連の共通的特徵に対して興味深い比較素材となる」と、我が国に対しこの 地域からのエールを送ってきている。我が国はこのエールに応えなければならな い。この地域の日本に対する関心は経済・貿易だけでなく教育の面でも非常に高 いものがあることを知らなければならない。

我が国は現在置かれているオセアニア地域の現状を直視することが必要であり、 世界的な視野からこの地域の教育のもつ意味を位置つけることが重要である。

\section{2. オセアニア教育研究の現状}

我が国に拈けるオセアニア教育研究は、次に示す資料からも最近急速に増加す る傾向にあり喜ばしいことである。

まず、豪日交流基金在日事務所（東京）が1994年にオーストラリア学会の会員 を対象に実施したアンケート調査の結果によれば、（1999年第 2 回目の調査を実 施中）オセアニア研究関連の講座を開講していると回答したのは、 4 年制大学 41 校、短期大学 6 校、専門学校 2 校で延べ85講座を開講している。この数字は教育 学関連研究のみの数字ではなく、オセアニアを対象とする全領域の研究を包括し た数字であるが、回答を寄せなかった機関もあることから、実数はこれ以上であ ることは確実である。いずれにせよ、 4 年制大学の約 1 割でオセアニア研究を対 
象とする講座が開講さ

れているわけで注目し

\begin{tabular}{ccccccc}
\hline & 1992 & 1993 & 1994 & 1995 & 1996 & 1997 \\
\hline オーストラリア & 11 & 19 & 18 & 19 & 28 & 21
\end{tabular}

てょい。これを、教育

ニュージーランド

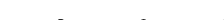

学関連研究に限定して

その他オセアニア

$\begin{array}{llll}2 & 4 & 1 & 2\end{array}$

ぞのような成果が報告されているかを国立教育研究所編の『教育研究論文索引』 （東京法令出版刊）に過去 6 年間に掲載された論文数でみると上表の通りであり、 近年急速に増加していることが明らかである。

もちろん、国立教育研究所がこの索引を作成するについては、一部の限定され た紀要や雑誌等を用いているので、全国の研究者の成果を網羅しているとはいえ ず、これ以上になることが予想される。いずれにせよ、増加している状況を概観 することはできょう。

また、文部省科学研究費の総合研究や特定研究プロジェクトにも、最近はオセ アニア地域が一地域として位置づけられて研究者が加わり、多くの成果を報告し ている。具体的なプロジェクトに関してはここでは割愛するが、この地域の研究 に貢献していることは衆目の一致するところである。

さらに、オセアニア教育学会（前オーストラリア研究会）の活動も、我が国の この地域の研究に一定の貢献をしているといえょう。この学会は既に紀要を 5 号 まで発行して扣り、論文21本、研究ノート 2 本、現場報告 2 本、書評 1 本が収録 されている。これは、上記の国立教育研究所編の『教育研究論文索引』には収録 されていないため、これらの成果を文部省科学研究費の総合研究・特定研究プロ ジェクトで報告された成果と総合すると、相当数の研究成果が発表されているこ とになる。

我が国のオセアニア教育研究の現状を紹介したが、特筆すべきことは、若手の 研究者がこれらの研究の中核になるまでに成長してきたことである。まだ数は少 ないものの、彼らの豊かな発想と行動力が今後の比較教育学研究に注目すべき展 望を開き、新しい可能性を生み出してくれることを期待したい。

\section{3. オセアニア地域研究の可能性}

オセアニア地域は歴史は浅く、かつほとんどが英連邦の傘下にあった。した がって、英国の影響が種々の面で残っている。しかし、独立後はそれぞれ独自の 
特集 比較教育学の新展開—そその可能性と展望

方向を模索し、特にオーストラリアとニュージーランドは着実に国力をつけてき た。国家は構成する国民のための教育制度を整備してきており、我が国から見た 場合、研究すべき領域は多いといえる。

この地域最大の国であるオーストラリアは、人口は少ないものの広大な国土を 6 州 2 直轄区に分割していることから、連邦政府が大枠では共通のものを打ち出

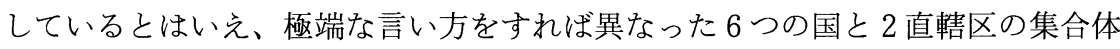
といえるほど特色をもっている。その上、基本的に地域住民主体の国であり、教 育行政もその立場から展開しているところから、州別の特色を把握し教育の独自 性を研究することが必要となる。中には我が国の現状を検証する場合に、例光ば 教育行政の基本的な考方方、英語を話せない子どもが入学・転入してきた場合の 言語教育など多くの示唆が得られるものもある。また、オーストラリアを構成す る国民は世界100カ国以上からの移民であり、彼らが作りあげた地域社会の特性、 言語や慣習などを研究の対象とすることも與味の尽きない領域である。先住民の 教育について地域社会自体を対象とした研究、及び国・州などの先住民に対する 教育施策・保障のあり方なども関心の集まる領域である。

ニュージーランドは、国全体の人口が横浜のそれと大差のない小国ではあるが、 オーストラリアよりも英国の影響を色濃く残している。国内をみると研究すべき 分野は多く残っている。1980年代末の教育行政改革はそれまでの中央集権的なも のから、学校現場に権限の委譲をはかるといら方向転換を実施した。南島と北島 から成る同国は、民族構成からも特色がみられ、南島はヨーロッパ系移民が大部 分を占めるのに対し、北島は南太平洋諸国からのポリネシア系移民、先住民マオ リ、アジア系移民などが目立つ地域である。この背景から、住民の意識に差があ り、教育行政改革への対応が異なる現実がみられる。また、国の先住民マオリに 対する対応が、オーストラリアの先住民アボリジニーに対するものとは大きな違 いがあることも注目すべき点である。つまり、ニュージーランド教育省はマオリ 人がマオリ語でマオリの子どもを教育する教育機関の設置を認め、多くのマオリ の子どもがそこで教育を受けている。彼らが成長した段階でニュージーランド社 会にどのように位置づけられるのか、国家全体の視点から今後の展開が注目され る。

オセアニア地域を構成するポリネシア、ミクロネシア、メラネシア地域の国々 
は、前記 2 カ国に若者を送り込み援助を受けて人材養成を委託したり、加えて南 太平洋大学を中心に国家の指導的人材の養成を積極的に進めている。しかしなが ら、その状況については我が国では情報がそしいのが現状である。この地域と オーストラリア、ニュージーランドとの教育的関係など明らかにすべき課題であ る。

オセアニア地域の国々の教育で、いわば総論に当たるべき視点を挙げ可能性に ついて記した。今後さらに進めるべき、いわば各論についてはこれ以外にも多く の分野がある。例えば移民に対する言語教育、遠隔地教育、教員養成、就学前教 育、特殊教育、私学教育等々挙げればきりがない。中には我が国に大きな示唆を 与える分野もあり、この地域の教育研究には大きな可能性がある。

\section{4. 地域研究の課題と方法}

オセアニア地域の教育研究の可能性と視点について記したが、我が国の比較教 育研究がどのようなスタンスでこの地域の教育研究を進めようとするのかを確認 しておくことが必要と考える。従来の我が国の研究は外国の教育研究から得るも のを求める傾向が強すぎてはいなかったか。我が国にとって得るものがなければ 研究の意味がないとする意識があったのではないか。今後の我が国の比較教育研 究は、その国の教育が世界的な視野からみてどのよらに位置づけられ、世界の教 育の中でぞのような有意性をもつかの観点から研究することこそ必要ではないか。 もらろん、我が国の教育に示唆を与えるものを積極的に研究し、受容することも 重要であることは異論のないことである。しかし、これだけで「良し」とする時 代ではない。世界各国はそれぞれの理念のもと、種々の条件を克服して独自の教 育制度を確立し、教育政策を策定してその国民に最善の教育を保障しよらとして いる。情報化時代で狭くなった世界の状況を冷静にみつめて、必要ならば積極的 な教育援助を効率的になし得るための情報の収集、分析、方法を研究することも 比較教育研究の使命の一つであると考える。オセアニア地域教育の研究は、まさ にこの観点から深めるべきもので、研究を通して我が国にとって必要な点、失っ てはいけない点があれば率直に施策に反映させる努力を関係当局に働さかけ、一 方、我が国が手をさしのべる点が見つかれば積極的に可能な知的援助等を学会と して公的機関に要請する必要がある。 
特集 比較教育学の新展開—その可能性と展望

この観点から地域研究にとって必要とされる方法を記したい。

第一は、地域調査（フィールドワーク）の必要性である。本論の対象とするオ セアニア地域でも、オーストラリアやニュージーランドについてはある程度の先 行研究が発表され、文献の入手も可能である。しかし、決して文献研究だけでは 十分でない。なぜならば、上記したように国民本位の政治体制が強く、極端にい えば連邦段階や州段階の選挙の度に多くの面で改革がなされている。教育が選挙 の争点になっている場合が多く、改正された最新の情報を得ることは日本にいて は不可能である。特に南太平洋地域の諸国については最新の資料・文献の入手は 困難で、地域調査（フィールドワーク）で資料を収集することが最善の方法であ る。地域調査は地域性、地域住民の教育に対する意識、自然環境などを肌で感じ、 住民との直接的な接触を通して理解を深めることが可能であり、地域調查は避け て通ることのできない法である。第二は、国全体を一括することの危険性であ る。オーストラリアの場合は国段階、州段階、地域段階の 3 段階、ニュージーラ ンドについては南島と北島個々の地方教育事務所段階までの考察、南太平洋なら ばポリネシア等地域別の考察が必要である。なぜならば、国民本位の政治体制の もとに教育の権限委譲が進んで招り、それ卆れ独自の方針のもとで教育を実施し ているからである。よく「オーストラリアの○○教育に関する研究」と題するも のが散見されるが、連邦・全州・区についての記述があれば理解できるが、一部 の地域を対象とした研究ならば自省すべきである。第三は、民族構成を的確に把 握することである。オセアニア地域は多民族国家が多く、それだけ多様な政治・ 文化・慣習等が根づている。これらの背景を無視して教育問題だけを取り上げ ても無意味となろう。本稿では最も重要な部分だけを取り上げたが、他は紙面の 都合で割愛する。 